\title{
Somatic embryogenesis from stem thin cell layers of Dendrobium aqueum
}

\author{
S. PARTHIBHAN ${ }^{1}$, M. VENKATESWARA RAO $^{1 *}$, J.A. TEIXEIRA DA SILVA ${ }^{2}$, \\ and T. SENTHIL KUMAR ${ }^{1}$
}

Department of Botany, Bharathidasan University, Tiruchirappalli - 620024, India ${ }^{1}$

P.O. Box 7, Miki-cho Post Office, 3011-2, Ikenobe, Kagawa 761-0799, Japan ${ }^{2}$

\begin{abstract}
An efficient in vitro regeneration protocol through somatic embryogenesis was established from stem transverse thin cell layers (tTCLs) of Dendrobium aqueum Lindley, an imperiled orchid. This study outlines the induction and successive maturation stages of $D$. aqueum somatic embryos (SEs). The tTCLs $(\sim 0.5 \mathrm{~mm}$ thick) cultured on halfstrength Murashige and Skoog (MS) medium containing cytokinins and auxins, either individually or in combination, produced embryogenic callus (EC). Treatment with $0.5 \mathrm{mg} \mathrm{dm}^{-3}$ zeatin induced EC in $41.42 \%$ of tTCLs. As many as 42.66 globular SEs per tTCL were formed in the presence of $1.5 \mathrm{mg} \mathrm{dm}^{-3} N^{6}$-(2-isopentyl) adenine (2iP) but only on $10.33 \%$ of explants. The combined treatment of $2 \mathrm{iP}\left(1.5 \mathrm{mg} \mathrm{dm}^{-3}\right)$ and $0.5 \mathrm{mg} \mathrm{dm}^{-3}$ 6-benzyladenine resulted in 34 globular SEs on $14.7 \%$ of tTCLs whereas the combination of $2 \mathrm{iP}$ and $1.0 \mathrm{mg} \mathrm{dm}$ indole-3-butyric acid (IBA) induced 7.4 globular SEs on $52.33 \%$ of tTCLs. Supplementation of activated charcoal, amino acids, and antioxidants alleviated browning at all the concentrations tested, but the EC response declined. The addition of $0.5 \mathrm{mg} \mathrm{dm}^{-3}$ polyvinylpyrrolidone to $1.5 \mathrm{mg} \mathrm{dm}^{-3} 2 \mathrm{iP}$ and $1.0 \mathrm{mg} \mathrm{dm}^{-3}$ IBA produced 24 SEs on $19.89 \%$ of tTCLs suggesting that the EC and SEs can be effectively induced by individual cytokinins whereas the synergistic treatments with other compounds can only enhance the induction of EC. Histological observations of EC showed the formation of globular SEs from sub-epidermal regions. Successive developmental stages of globular SEs and the intermediate stage of protocorm like bodies until the formation of plantlets were observed. The plantlets obtained through SEs showed no morphological variations, and inter simple sequence repeat profiles also confirmed the genetic fidelity of in vitroderived progeny with high monomorphism $(97.78 \%)$. In conclusion, the use of stem tTCLs is an effective method to produce SEs through indirect somatic embryogenesis in D. aqueum.
\end{abstract}

Additional key words: auxins, cytokinins, epiphyte, embryogenic callus, in vitro culture, ISSR, protocorm like bodies.

\section{Introduction}

The Orchidaceae, one of the largest, most highly evolved, and diverse families of flowering plants, contains about 35000 species belonging to 850 genera (Hossain et al. 2013). Dendrobium is a large genus of the Orchidaceae with about 1600 species worldwide, and 116 can be found in India (Misra 2007). Dendrobium aqueum Lindley is an endemic orchid distributed in the Kolli hills (Namakkal) and Shervarayans (Salem) of Eastern Ghats, Tamil Nadu, India (Matthew 1983). Natural D. aqueum populations are declining due to

anthropogenic activities such as the collection of orchids and habitat destruction. This species was categorized as near threatened in 2000 by the International Union for Conservation of Nature and Natural Resources (Kumar et al. 2001), and subsequent field studies at the Kolli hills have recorded a continual decline of this natural population (Sudhakar Reddy et al. 2005). Studies on the phenology and in vitro propagation through asymbiotic seed germination and protocorms have been already achieved in D. aqueum (Parthibhan et al. 2012,

Submitted 13 June 2017, last revision 22 November 2017, accepted 4 December 2017.

Abbreviations: 2iP - $N^{6}$-(2-isopentyl) adenine; AC - activated charcoal; BA - 6-benzyladenine; DSE - direct somatic embryogenesis; EC - embryogenic callus; IAA - indole-3-acetic acid; IBA - indole-3-butyric acid; ISSR - inter simple sequence repeat; KN - kinetin; MS - Murashige and Skoog; NAA - 1-naphthalene acetic acid; PGR - plant growth regulator; PLB - protocorm-like body; PVP polyvinylpyrrolidone; SE - somatic embryo; tTCL - transverse thin cell layer; TDZ - thiadiazuron; ZEA - zeatin.

Acknowledgements: We sincerely acknowledge the financial assistance from the Ministry of Environment, Forest and Climate change, New Delhi, Government of India, and the Rajiv Gandhi National Fellowship (UGC). The corresponding author thanks the University Grants Commission (UGC), New Delhi, for providing an Emeritus Fellowship.

* Corresponding author; e-mail: mvrao_456@yahoo.co.in 


\section{5a,b).}

Conventional propagation of Dendrobium by seed germination requires a suitable mycorrhizal fungus due to the absence of a mature endosperm in the seed (Teixeira da Silva et al. 2015c), although seeds can be germinated in vitro under asymbiotic conditions (Teixeira da Silva et al. 2015b). In Dendrobium, a wide range of explants including apical buds, flower buds, rhizomes, seeds, leaves, and root tips can produce protocorm-like bodies (PLBs), callus, or directly shoots, which ultimately result in the formation of plantlets (Teixeira da Silva et al. 2015a). Thin cell layers (TCLs) which consist of a small amount of tissue comprising very few cell layers can be prepared from almost any plant organ. These, when cut longitudinally, are referred to as ITCLs, and when cut transversally, are referred to as tTCLs (Teixeira da Silva 2013, Teixeira da Silva and Dobránszki 2013). The regeneration of PLBs and shoot buds from TCLs has been possible from shoots, shoot tips, nodes, or PLBs in Dendrobium species (Table 1 Suppl.). The PLBs in orchids are de facto somatic embryos (Teixeira da Silva 2014, Teixeira da Silva and Winarto 2016), a phenomenon that was previously confirmed by histology in this and in another orchid genus, Phalaenopsis (Lee et al. 2013). Somatic embryogenesis or PLB induction in orchids is often contingent upon the type and ratio of auxin and cytokinin during in vitro propagation (Hossain et al. 2013).

Dendrobium species possess various medicinal properties (Teixeira da Silva and Ng 2017) and $D$. aqueum is known for its free-radical scavenging and antiglycation potential, and phytochemicals such as

\section{Materials and methods}

Explants and culture conditions: Shoots of uniform height $(\sim 5 \mathrm{~cm})$ with a minimum of four nodes obtained from in vitro grown seedlings were used as the explant source (Parthibhan et al. 2012). The shoots $(\sim 4.5 \mathrm{~cm})$ were prepared by removing the shoot tip, leaves, protocorm, and roots. Stems were then cut transversely into slices of $0.5 \mathrm{~mm}$ thick (i.e., tTCLs) using a surgical blade (Glass Van, Faridabad, India) and used as explants for embryogenic callus (EC) induction.

The tTCLs were cultured on a half-strength (macronutrients) MS medium supplemented with $2 \%$ $(\mathrm{m} / \mathrm{v})$ sucrose and different concentrations $(0.1-3.0$ $\mathrm{mg} \mathrm{dm}^{-3}$ ) of cytokinins, viz., 6-benzyladenine (BA), $N^{6}$-(2-isopentyl) adenine (2iP), kinetin (KN), thidiazuron (TDZ), and zeatin (ZEA) to induce an embryogenic callus (EC). To evaluate the synergistic effect of cytokinins and auxins as a way to improve EC induction and proliferation, the cytokinins that responded best on EC induction, $\mathrm{BA}, 2 \mathrm{P}$, and $\mathrm{KN}$, were combined with three auxins, viz., indole-3-acetic acid (IAA), indole-3-butyric acid (IBA), and 1-naphthalene acetic acid (NAA), in a wide range of concentrations $\left(0.01-2.0 \mathrm{mg} \mathrm{dm}^{-3}\right)$. In order to enhance EC production by preventing or minimizing the browning of explants and EC, activated flavonoids, cyanogenic glycosides, and tannin (Maridass et al. 2008, Mukherjee et al. 2012).

The TCLs system has a few applications in Dendrobium in vitro culture (Table 1 Suppl.). When cultured on a Murashige and Skoog (1962; MS) basal medium without plant growth regulators (PGRs), D. draconis tTCLs remain green for up to $1-2$ weeks and then gradually become brown and die (Rangsayatorn 2009). Browning or blackening explants and calluses occurs as a result of phenolic secretions from the wounded cells, during sectioning tissue from shoot tips, leaves, or PLBs (Kaewubon et al. 2015). The incidence of browning in the medium and explants on TCL cultures were frequently reported in several orchids such as $D$. fimbriatum, D. chrysotoxum, D. candidum, D. draconis, D. nobile, Cymbidium spp., and Phalaenopsis cornu-cervi (Roy and Banerjee 2003, Malabadi et al. 2005, Teixeira da Silva et al. 2006, Roy et al. 2007, Zhao et al. 2007, Rangsayatorn 2009, Vyas et al. 2010, Rittirat et al. 2012). In these studies, shoot production and embryogenic response of the explants decrease. However, the addition of coconut water at $5 \%$ ( $\mathrm{v} / \mathrm{v})$ or optimization of PGR concentrations decreases necrosis and enhances PLB production (Roy and Banerjee 2003, Roy et al. 2007, Vyas et al. 2010).

As a part of a wider ex situ conservation strategy for $D$. aqueum, the present research was carried out to develop a protocol to induce somatic embryos (SEs) from tTCLs. Furthermore, the genetic fidelity of SE-derived plantlets was assessed using inter simple sequence repeat (ISSR) markers. charcoal (AC; $1 \%, \mathrm{~m} / \mathrm{v})$, an amino acid arginine $\left(5-100 \mathrm{mg} \mathrm{dm}{ }^{-3}\right)$, and two antioxidants glutathione $\left(5-100 \mathrm{mg} \mathrm{dm}^{-3}\right.$ ) and polyvinylpyrrolidone (PVP; $0.1-1.0 \mathrm{mg} \mathrm{dm}^{-3}$ ) were tested in the MS medium supplemented with $1.5 \mathrm{mg} \mathrm{dm}^{-3} 2 \mathrm{iP}$ and $1.0 \mathrm{mg} \mathrm{dm}^{-3}$ IBA. All the culture media were solidified with $0.7 \%$ $(\mathrm{m} / \mathrm{v})$ agar. The $\mathrm{pH}$ was adjusted to $5.7 \pm 0.2$ with $0.1 \mathrm{M}$ $\mathrm{NaOH}$ or $0.1 \mathrm{M} \mathrm{HCl}$ before autoclaving at $121{ }^{\circ} \mathrm{C}$ and $1.06 \times 10^{5} \mathrm{~N} \mathrm{~m}^{-2}$ for $15 \mathrm{~min}$. The cultures were incubated at a temperature of $23 \pm 2{ }^{\circ} \mathrm{C}$, a 16 -h photoperiod, and a photosynthetic photon flux density of $35 \mu \mathrm{mol} \mathrm{m} \mathrm{m}^{-2} \mathrm{~s}^{-1}$ provided by cool white fluorescent lamps (TL-D Super 80, Philips, Gurgaon, India). All chemicals and reagents were purchased from HiMedia (Mumbai, India).

Histology: Some of the EC with SEs were fixed in an FAA (formalin + acetic acid $+70 \%$, v/v, ethanol, 1:1:18, $\mathrm{v} / \mathrm{v} / \mathrm{v}$ ) solution (Zhao et al. 2007). The EC was neither dehydrated in an ethanol series nor embedded in wax since the EC with developing SEs tended to shrink during the dehydration process. Fine sections, which were made manually using thin commercial blades (SuperMax-SS, Thane, India) were stained with $1 \%(\mathrm{~m} / \mathrm{v})$ safranin and then observed and photographed under a triangular 
compound microscope (GTR-22A, GETNER, Haryana, India).

Genomic DNA extraction, primers, PCR amplification, and ISSR markers: Genomic DNA was extracted from leaves of an in vitro mother plant and six plantlets (randomly selected) raised from somatic embryogenesis using the cetyltrimethyl ammonium bromide method as described by Wang et al. (2009) with a modification. Five ISSR primers, UBC-812 [(AC)8C], UBC-826 [(GA)8YC], UBC-866 [(AC)8AT], I-2 [(AC)8AG], and I-4 [(AC)8TG], which were already reported to show a high polymorphism in Dendrobium species (Wang et al. 2009), were randomly selected for the study. PCR amplification was performed in a thermal cycler (Eppendorf, Hamburg, Germany) using $10 \mathrm{~mm}^{3}$ of reaction mixture containing $7 \mathrm{~mm}^{3}$ of PCR master mix, $1 \mathrm{~mm}^{3}$ of genomic DNA, $1 \mathrm{~mm}^{3}$ of sterile double distilled water and 1 unit of Taq DNA polymerase, and PCR conditions were adopted from Wang et al. (2009).

PCR products were electrophoresed on $1.2 \%(\mathrm{~m} / \mathrm{v})$ agarose gels which contained $3 \mathrm{~mm}^{3}$ of ethidium bromide stain. The electrophoretic patterns of the PCR products were recorded digitally using a Gel-Doc-2000 image analysis system (Bio-Rad, Hercules, PA, USA). The amplified fragments were scored for the presence (1) and absence (0) of homologous bands, and a matrix of ISSR data was assembled. The experiment was repeated again, and only the reproducible fragments were scored for polymorphism analysis.

\section{Results}

Stem tTCLs cultured on a half-strength MS basal medium (control) remained green for two to three weeks and then gradually turned brown, becoming completely necrotic. In contrast tTCLs cultured on the same medium supplemented with cytokinins remained green and induced EC as well as direct SEs after five weeks. A high percentage of explants $(41.42 \%)$ induced green compact EC in response to $0.5 \mathrm{mg} \mathrm{dm}^{-3} \mathrm{ZEA}$ (Table 1). When the concentration of ZEA increased, EC induction decreased, and yellowish-green callus was produced. Subsequently, on the media with 0.5 and $0.1 \mathrm{mg} \mathrm{dm}^{-3} \mathrm{BA}, 16.83$ and $16.27 \%$ of tTCLs induced a green EC with compact globular SEs (Fig. 1A).

On the other hand, $2 \mathrm{iP}$ at all concentrations $(0.1-3.0$ $\mathrm{mg} \mathrm{dm}^{-3}$ ) produced pale green to green and yellow friable ECs with loosely packed SEs at low frequencies. The highest percentage of explants $(10.75 \%)$ produced a yellow EC in response to $1.5 \mathrm{mg} \mathrm{dm}^{-3} 2 \mathrm{iP}$ (Fig. 1E,F). $\mathrm{KN}$ and TDZ at $1.5 \mathrm{mg} \mathrm{dm}^{-3}$ induced yellowish-green and green callus, respectively in 8.40 and $8.50 \%$ of tTCLs. A few explants $(2.74 \%)$ induced a green compact callus on the TDZ-containing medium. Morphologically, the growth of developing globular SEs was better in response to BA than to other cytokinins.

In ZEA-induced callus, the green callus turned yellow
Ex vitro establishment of plantlets: The SE-derived plantlets with 2 - 3 roots from all cultures ( 25 weeks old) were hardened and acclimatized as in Parthibhan et al. (2015a). In brief, the plantlets with 4 - 5 fully expanded leaves and roots were cultured on a half-strength MS basal medium without sucrose for 5 weeks, then transferred into small paper pots $(4 \mathrm{~cm}$ wide $\times 6 \mathrm{~cm}$ high) containing a $1: 1(\mathrm{~m} / \mathrm{m})$ mixture of brick pieces and charcoal. Moss was laid over the potting mixture and covered with polyethylene bags to maintain high relative humidity. The substrate was regularly moistened with a half-strength MS liquid medium and kept in a culture room at $25 \pm 1{ }^{\circ} \mathrm{C}$, a 16 -h photoperiod, and a photosynthetic photon flux density of $35 \mu \mathrm{mol} \mathrm{m} \mathrm{m}^{-2} \mathrm{~s}^{-1}$ for 4 - 6 weeks. Finally, the well-hardened plantlets were transferred to a greenhouse.

Experimental design and data analysis: Experiments were completely randomized. Each treatment had 12 explants per Petri dish and with three replicates. The quality and frequency of EC and SE were recorded after eight weeks of culture. The number of globular SEs was counted under a dissecting microscope (DM-2, Weswox Optik, Haryana, India) after 15 weeks of culture. The percentage data were arcsine transformed before statistical analysis. All data were analyzed by $A N O V A$ using Statistical Package for the Social Sciences (SPSS $v$. 18) software (IBM SPSS, Chicago, IL, USA). Means were differentiated at the $\alpha=0.05$ level of significance using Duncan's multiple range test (DMRT).

and became necrotic after eight weeks of culture (Table 1). On the other hand, green and yellowish-green callus that formed in the presence of $0.5 \mathrm{mg} \mathrm{dm}^{-3} \mathrm{BA}$, $1.5 \mathrm{mg} \mathrm{dm}^{-3} 2 \mathrm{iP}$, and $1.5 \mathrm{mg} \mathrm{dm}^{-3} \mathrm{KN}$ continued to proliferate well and developed globular SEs (except for BA) after 8 - 12 weeks on the same medium. Therefore, to enhance the frequency of ECs, $0.5 \mathrm{mg} \mathrm{dm}^{-3} \mathrm{BA}$ was combined with $1.5 \mathrm{mg} \mathrm{dm}^{-3} \mathrm{KN}$ and $1.5 \mathrm{mg} \mathrm{dm}^{-3} 2 \mathrm{iP}$. In addition, $0.5 \mathrm{mg} \mathrm{dm}^{-3} \mathrm{BA}$ and $1.5 \mathrm{mg} \mathrm{dm}^{-3} 2 \mathrm{iP}$ were combined with different auxins to improve EC and SE production.

The combination of two cytokinins, BA $\left(0.5 \mathrm{mg} \mathrm{dm}^{-3}\right)$ and $\mathrm{KN}\left(1.5 \mathrm{mg} \mathrm{dm}^{-3}\right)$ improved EC induction frequency to $20 \%$ via the formation of a yellowish-green callus. In contrast, $0.5 \mathrm{mg} \mathrm{dm}^{-3} \mathrm{BA}$ with $1.5 \mathrm{mg} \mathrm{dm}^{-3} 2 \mathrm{iP}$ reduced the frequency of EC to $14.67 \%$, and pale green to green callus formed (Table 2). From the two cytokinin combinations, callus that formed on medium with $\mathrm{BA}+2 \mathrm{iP}$ was healthier (no browning) than on medium with $\mathrm{BA}+\mathrm{KN}$. Callus that formed in response to the $\mathrm{BA}+\mathrm{KN}$ combination was yellowish-green, and further proliferation was severely affected by tissue browning.

Auxins (IAA, IBA, and NAA) at $0.01-1.0 \mathrm{mg} \mathrm{dm}^{-3}$ effectively increased the frequency of EC induction when combined with the cytokinins BA and 2iP (Table 2). The 
synergistic effect of $2 \mathrm{iP}\left(1.5 \mathrm{mg} \mathrm{dm}^{-3}\right)$ with these auxins was more effective than that of BA on both EC induction and callus proliferation. The highest $(53.33 \%)$ induction of green and yellowish-green calluses was recorded on $2 \mathrm{iP}\left(1.5 \mathrm{mg} \mathrm{dm}^{-3}\right.$ ) with $1.0 \mathrm{mg} \mathrm{dm}^{-3}$ IBA (Fig. 1B),

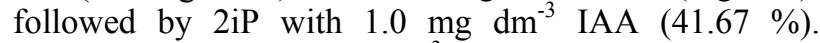
Among the BA $\left(0.5 \mathrm{mg} \mathrm{dm}^{-3}\right)$ and auxin combinations, the best response $(33.33 \%)$ was on the medium with $0.1 \mathrm{mg} \mathrm{dm}^{-3} \mathrm{NAA}$ and $1.0 \mathrm{mg} \mathrm{dm}^{-3}$ IAA, respectively (Table 2). Poor EC induction between 8.33 and $16.00 \%$ was noted when the highest auxin concentration $\left(2.0 \mathrm{mg} \mathrm{dm}^{-3}\right)$ was used.

Treatments employing AC, arginine, PVP, and glutathione prevented early browning in tTCLs, but EC induction did not improve. The tTCL explants cultured on the medium supplemented with $\mathrm{AC}$ failed to respond further. The highest number of tTCLs formed green ECs $(18.33 \%)$ on the medium supplemented with $50 \mathrm{mg} \mathrm{dm}^{-3}$ arginine (Fig. 2) and $0.5 \mathrm{mg} \mathrm{dm}^{-3}$ PVP whereas only $11.67 \%$ of green ECs was formed in response to $100 \mathrm{mg} \mathrm{dm}^{-3}$ glutathione (Figs. 3, 4).

The EC induced from any treatment developed further
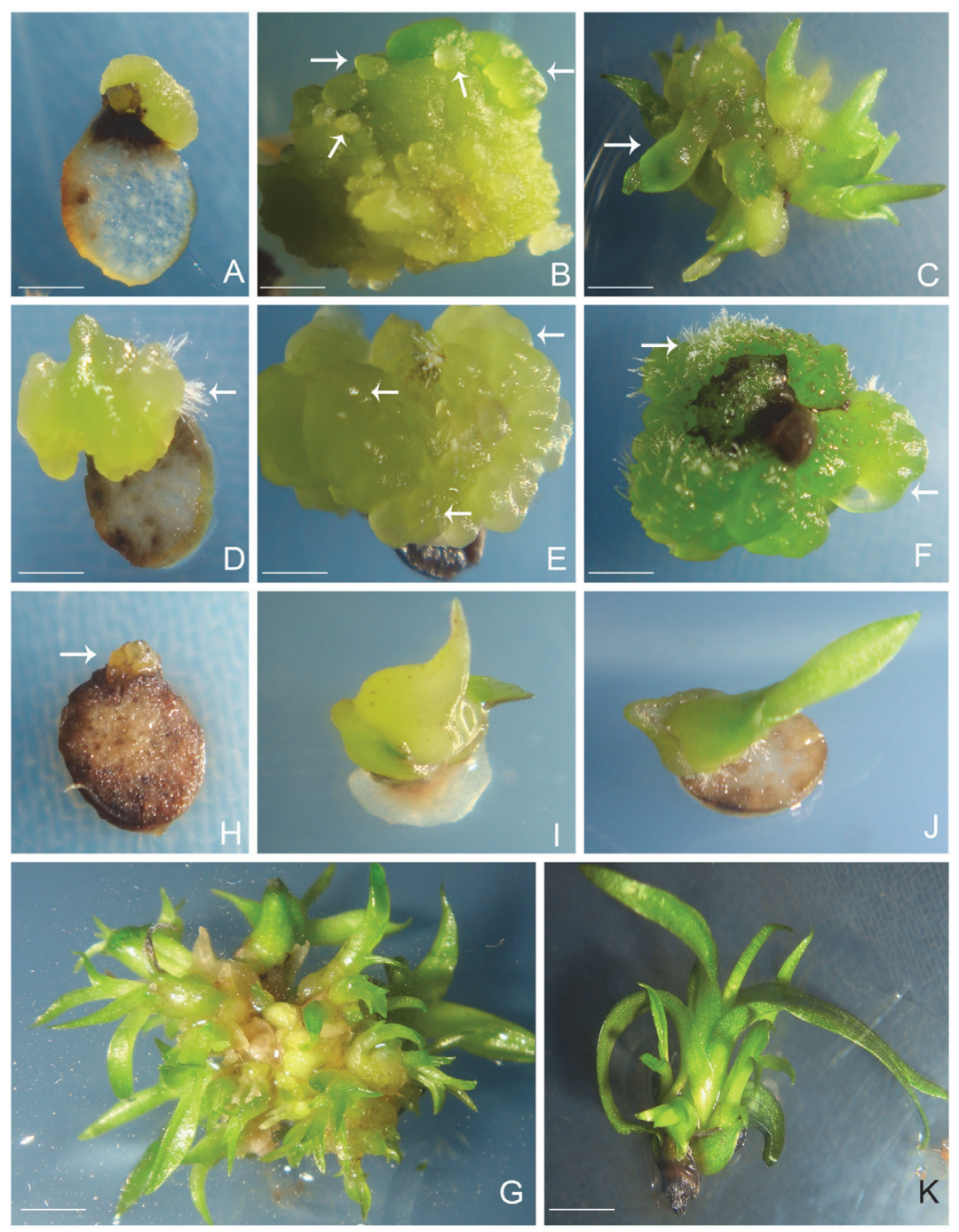

Fig. 1. Indirect somatic embryogenesis $(A-G)$ and direct somatic embryogenesis $(H-K)$ on half-strength MS from stem thin cell layers (TCLs) of Dendrobium aqueum: $A$ - a dedifferentiated green compact embryogenic callus (EC) induced from the sub-epidermal region of a stem TCL in the presence of $0.5 \mathrm{mg} \mathrm{dm}^{-3} \mathrm{BA} ; B$ - redifferentiated globular and heart-shaped somatic embryos (SEs) developed from the compact surface of proliferated embryonic callus (EC) in response to $1.5 \mathrm{mg} \mathrm{dm}^{-3} 2 \mathrm{iP}$ and $1.0 \mathrm{mg} \mathrm{dm}{ }^{-3} \mathrm{IBA}$; $C$ a redifferentiated, elongated, and torpedo-like SE with a leaf primordium (the arrow) and late-stage protocorm-like bodies (PLBs) with a leafy shoot initial emerging in response to $1.5 \mathrm{mg} \mathrm{dm}^{-3} 2 \mathrm{iP}$ with $0.01 \mathrm{mg} \mathrm{dm}^{-3} \mathrm{NAA} ; D$ dedifferentiated green, compact EC with sunken globular embryos (with rhizoids) in response to $0.1 \mathrm{mg} \mathrm{dm}^{-3} \mathrm{BA} ; E$ and $F$ - aerial and inverted views of proliferated EC with multiple, compact, sunken globular SEs and PLBs with a leafy shoot initial and rhizoids in response to $1.5 \mathrm{mg} \mathrm{dm}^{-3} 2 \mathrm{iP} ; G-\mathrm{SE}-$ derived shoots with more than two leaves; $H-J$ - direct SE (PLB) induction (arrow) and development in response to $0.1 \mathrm{mg} \mathrm{dm}^{-3}$ of $\mathrm{KN}$, BA, and ZEA each, respectively; $K$ - multiple shoot formation obtained from a direct SE in response to $1.5 \mathrm{mg}^{-3} 2 \mathrm{iP}$, $0.01 \mathrm{mg} \mathrm{dm}^{-3} \mathrm{NAA}$, and $0.3 \mathrm{mg} \mathrm{dm}^{-3}$ polyvinylpyrrolidone. Scale bars: $2 \mathrm{~mm}(A$ to $K)$. 
Table 1. Embryogenic callus induction from stem transverse thin cell layers of Dendrobium aqueum on half-strength Murashige and Skoog medium supplemented with different cytokinins. The experiment was repeated 3 times with 12 explants per treatment. Means $\pm \mathrm{SEs}, n=12$. Values within each column with different letters are significantly different $\left(P \leq 0.05\right.$; DMRT). 2iP - $\mathrm{N}^{6}-(2$-isopentyl $)$ adenine; BA - 6-benzyladenine; EC - embryogenic callus; G - green; KN - kinetin; LG - light/pale green; SE - somatic embryo; TDZ - thidiazuron; W - white; Y - yellowish; YG - yellowish green; ZEA zeatin; - means no response.

\begin{tabular}{|c|c|c|c|c|c|c|c|}
\hline \multirow[t]{2}{*}{ Cytokinins } & \multirow{2}{*}{$\begin{array}{l}\text { Concentration } \\
{\left[\mathrm{mg} \mathrm{dm}^{-3}\right]}\end{array}$} & \multicolumn{3}{|c|}{ Indirect somatic embryogenesis } & \multicolumn{2}{|c|}{ Direct somatic embryogenesis } & \multirow[b]{2}{*}{$\begin{array}{l}\text { shoot length } \\
{[\mathrm{cm}]}\end{array}$} \\
\hline & & $\begin{array}{l}\text { callus response } \\
{[\%]}\end{array}$ & colour of EC & $\begin{array}{l}\text { SE number } \\
\left.\text { explant }^{-1}\right]\end{array}$ & $\begin{array}{l}\text { Response } \\
{[\%]}\end{array}$ & $\begin{array}{l}\text { SE number } \\
{\left[\text { explant }^{-1}\right]}\end{array}$ & \\
\hline \multirow[t]{6}{*}{ BA } & 0.1 & $16.27^{\mathrm{d}}$ & $\mathrm{G}$ & $2.33 \pm 0.57^{\mathrm{ghi}}$ & 8.33 & 1.00 & 0.70 \\
\hline & 0.5 & $16.83^{c}$ & $\mathrm{G}$ & $16.00 \pm 1.00^{\mathrm{b}}$ & - & - & - \\
\hline & 1.0 & $8.36^{\mathrm{f}}$ & YG & $4.33 \pm 0.57^{\mathrm{ef}}$ & - & - & - \\
\hline & 1.5 & $0.00^{1}$ & - & $0.00 \pm 0.00^{\mathrm{k}}$ & - & - & - \\
\hline & 2.0 & $0.00^{1}$ & - & $0.00 \pm 0.00^{\mathrm{k}}$ & - & - & - \\
\hline & 3.0 & $0.00^{1}$ & - & $0.00 \pm 0.00^{\mathrm{k}}$ & - & - & - \\
\hline \multirow[t]{6}{*}{$2 \mathrm{iP}$} & 0.1 & $6.66^{\mathrm{g}}$ & $\mathrm{G}$ & $3.00 \pm 1.00^{\mathrm{fgh}}$ & 8.33 & 1.00 & 0.60 \\
\hline & 0.5 & $8.38^{\mathrm{f}}$ & $\mathrm{G}$ & $3.33 \pm 0.57^{\mathrm{fg}}$ & - & - & - \\
\hline & 1.0 & $8.82^{\mathrm{f}}$ & PG & $15.00 \pm 1.00^{\mathrm{bc}}$ & - & - & - \\
\hline & 1.5 & $10.75^{\mathrm{e}}$ & $\mathrm{Y}$ & $42.67 \pm 0.58^{\mathrm{a}}$ & - & - & - \\
\hline & 2.0 & $6.52^{\mathrm{g}}$ & $\mathrm{Y}$ & $15.00 \pm 1.00^{\mathrm{bc}}$ & - & - & - \\
\hline & 3.0 & $5.43^{\mathrm{h}}$ & $\mathrm{Y}$ & $13.67 \pm 1.53^{\mathrm{c}}$ & - & - & - \\
\hline \multirow[t]{6}{*}{ TDZ } & 0.1 & $0.00^{1}$ & - & $0.00 \pm 0.00^{\mathrm{k}}$ & - & - & - \\
\hline & 0.5 & $0.00^{1}$ & - & $0.00 \pm 0.00 \mathrm{k}$ & - & - & - \\
\hline & 1.0 & $4.48^{i}$ & $\mathrm{G}$ & $1.67 \pm 0.58^{\mathrm{hij}}$ & - & - & - \\
\hline & 1.5 & $8.50^{\mathrm{f}}$ & $\mathrm{G}$ & $5.67 \pm 0.58^{\mathrm{de}}$ & - & - & - \\
\hline & 2.0 & $2.75^{\mathrm{k}}$ & G & $0.67 \pm 0.58^{\mathrm{jk}}$ & - & - & - \\
\hline & 3.0 & $0.00^{1}$ & - & $0.00 \pm 0.00^{\mathrm{k}}$ & - & - & - \\
\hline \multirow[t]{6}{*}{$\mathrm{KN}$} & 0.1 & $3.70^{j}$ & PG & $0.67 \pm 1.15^{\mathrm{jk}}$ & 8.33 & 1.00 & 0.55 \\
\hline & 0.5 & $5.33^{\mathrm{h}}$ & G & $6.67 \pm 1.53^{\mathrm{d}}$ & - & - & - \\
\hline & 1.0 & $6.85^{\mathrm{g}}$ & YG & $3.00 \pm 2.00^{\mathrm{fgh}}$ & - & - & - \\
\hline & 1.5 & $8.40^{\mathrm{f}}$ & YG & $1.00 \pm 1.00^{\mathrm{ijk}}$ & - & - & - \\
\hline & 2.0 & $4.53^{i}$ & G & $0.00 \pm 0.00^{\mathrm{k}}$ & - & - & - \\
\hline & 3.0 & $2.28^{\mathrm{k}}$ & $\mathrm{G}$ & $0.00 \pm 0.00^{\mathrm{k}}$ & - & - & - \\
\hline \multirow[t]{6}{*}{ ZEA } & 0.1 & $8.53^{\mathrm{f}}$ & $\mathrm{G}$ & $0.67 \pm 0.58^{\mathrm{jk}}$ & 8.33 & 1.00 & 0.35 \\
\hline & 0.5 & $41.42^{\mathrm{a}}$ & G & $3.67 \pm 1.15^{\mathrm{fg}}$ & - & - & - \\
\hline & 1.0 & $26.02^{b}$ & YG & $1.00 \pm 1.00^{\mathrm{ijk}}$ & - & - & - \\
\hline & 1.5 & $16.83^{c}$ & YG & $0.67 \pm 0.58^{\mathrm{jk}}$ & - & - & - \\
\hline & 2.0 & $8.50^{\mathrm{f}}$ & YG & $0.00 \pm 0.00^{\mathrm{k}}$ & - & - & - \\
\hline & 3.0 & $4.55^{i}$ & YG & $0.00 \pm 0.00^{\mathrm{k}}$ & - & - & - \\
\hline
\end{tabular}

and continued to grow on the same medium. Except for tissue browning, all cultures, irrespective of the callus induction medium employed, showed callus proliferation, and SE formation and multiplication. Developing EC displayed four colors, green, pale green, yellowish-green, and yellow. Green, pale green, and some yellowish-green callus formed SEs whereas yellow and yellowish-green callus turned brown and became necrotic.

Microscopic and histological observations of EC sections revealed different maturation stages of the SEs. Stem tTCLs consisted of an epidermis and a few layers of small polyhedral cells (Fig. $5 A$ ), which were packed at sub-epidermal regions, followed by large, scattered, and vacuolated cells. Initially, a green protuberance originated from the sub-epidermal region by periclinal and anticlinal cell divisions (Fig. $5 B, C$ ). Subsequent proliferation of these cells formed an EC, consisting of cells with a dense cytoplasm, prominent nucleus and vacuoles (Fig. $5 D, E$ ). However, successive growth of ECs and formation of SEs (Fig. $5 E-G$ ) depended on the type and combination of PGRs employed.

The structure of the ECs was generally compact and slightly friable at the surface (Fig. 1A,D). Globular SE initials were observed as either protuberances or closely packed clusters inside and/or on the surface of the callus mass, creating a friable surface (Fig. 5E). Clusters of SEs initially consisted of only globular SEs (Fig. 1 Suppl., Fig. 5E). However, subsequent lowering concentration of nutrients in the medium, and interruption of browning and necrosis in EC, instigated differences in maturation of the SEs. The globular SEs continued to enlarge and formed an asymmetric heart-shape SEs (Fig. 1 Suppl.). At maturity, the early heart-shape SEs formed either typical heart-shaped SEs (asymmetric) (Fig. 1 Suppl., 
Fig. 5E) or elliptical SEs that subsequently formed typical elongated torpedo-shaped (asymmetric) SEs or enlarged PLBs (Fig. 1 Suppl.). Bipolar SEs were characterized by the formation of a pointed shoot apex or cotyledonary leaf initiation and rhizoidal hairs, which appeared on opposite poles of the PLBs and torpedoshaped SEs (Fig. 1 Suppl.). Very few globular or heartshaped SEs that formed on yellowish-green and yellow calluses failed to develop further due to severe browning. Mature torpedo SEs and PLBs with a cotyledonary leaf (Fig. 5G) grew into rooted, leafy shoots (Fig. 1 Suppl.). The successive stages of SE maturation from globular to torpedo stages were hardly visible and difficult to measure since the SEs were compactly packed. In such cases, early globular SEs or shoots that developed later were evaluated.

The rate of SE formation and the quality of SEs varied with the concentration, type, and combination of PGRs. The highest number of SEs per tTCL (42.66) was recorded on the medium with $1.5 \mathrm{mg} \mathrm{dm}^{-3} 2 \mathrm{iP}$ alone followed by $1.5 \mathrm{mg} \mathrm{dm}^{-3} 2 \mathrm{iP}+0.5 \mathrm{mg} \mathrm{dm}^{-3} \mathrm{BA}$ (34 SE per explant) whereas the PVP $\left(0.5 \mathrm{mg} \mathrm{dm}^{-3}\right)$ supplemented medium formed only 24 SEs per tTCL (Fig. 3).

The cytokinins $2 \mathrm{iP}\left(1.0,2.0\right.$, and $\left.3.0 \mathrm{mg} \mathrm{dm}^{-3}\right)$ and BA $\left(0.5 \mathrm{mg} \mathrm{dm}^{-3}\right)$ individually induced about $14-16 \mathrm{SEs}$ per tTCL. When these concentrations were raised, or when other cytokinins were used, poor development of SE was observed forming only 1 - 13 SEs per tTCL. When BA $\left(0.5 \mathrm{mg} \mathrm{dm}^{-3}\right)$ was combined with any auxin, it had no distinct effect on the formation of SEs or PLBs except when used with $1.0 \mathrm{mg} \mathrm{dm}^{-3} \mathrm{IAA}$ at a later stage. On the other hand, 2iP when combined with auxins effectively induced EC and SEs. The highest values of

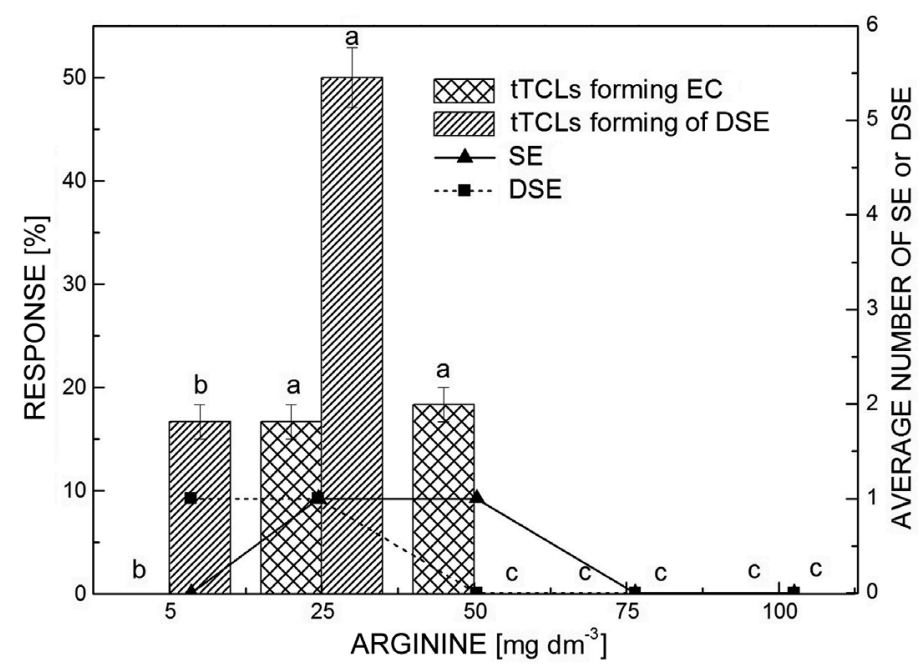

Fig. 2. Embryogenic callus (EC) induction and the number of somatic embryos (SEs) from stem transverse thin cell layers (tTCLs) of Dendrobium aqueum in response to arginine. Means \pm SDs, $n=12$, different letters indicate significantly different means $(P \leq 0.05$; DMRT). DSE - direct somatic embryogenesis.

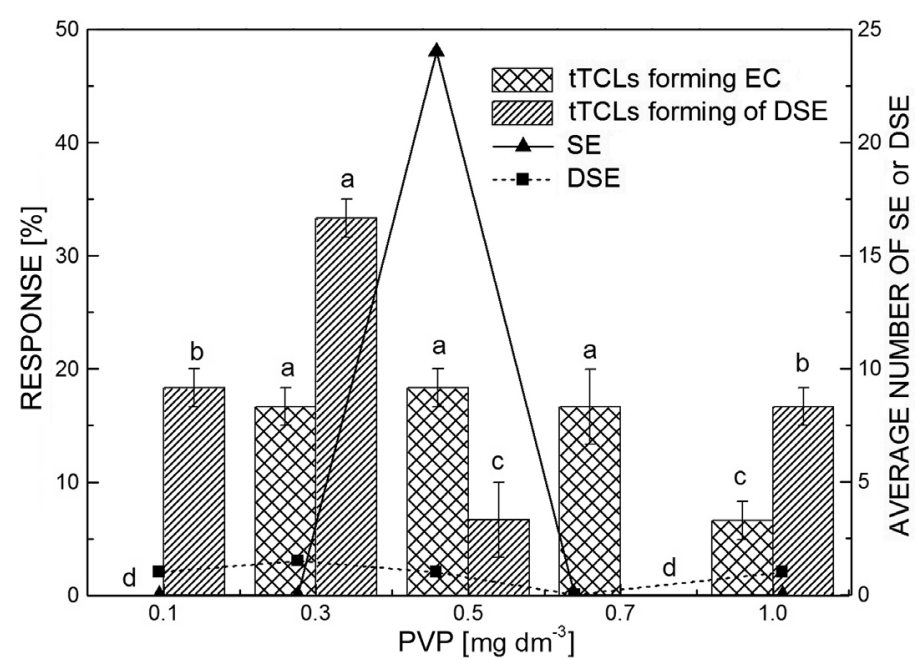

Fig. 3. Embryogenic callus (EC) induction and the number of somatic embryos from stem transverse thin cell layers (TCLs) of Dendrobium aqueum in response to polyvinylpyrrolidone (PVP). Means \pm SDs, $n=12$, different letters indicate significantly different means $(P \leq 0.05$; DMRT). DSE - direct somatic embryogenesis. 
Table 2. Effects of combined cytokinins and auxins on embryogenic callus induction from stem transverse thin cell layers (tTCLs) of Dendrobium aqueum. Means \pm SEs, $n=12$ (experiment was repeated 3 times with 12 explants per treatment). Values within each column with different letters are significantly different $(P \leq 0.05$; DMRT). IAA - indole-3-acetic acid; IBA - indole-3-butyric acid; NAA - 1-naphthalene acetic acid; PGR - plant growth regulator; - = no response.

\begin{tabular}{|c|c|c|c|c|c|c|}
\hline \multirow[t]{2}{*}{ PGRs } & \multirow{2}{*}{$\begin{array}{l}\text { Concentrations } \\
{\left[\mathrm{mg} \mathrm{dm}^{-3}\right]}\end{array}$} & \multicolumn{2}{|c|}{ Indirect somatic embryogenesis } & \multicolumn{2}{|c|}{ Direct somatic embryogenesis } & \multirow[b]{2}{*}{$\begin{array}{l}\text { shoot length } \\
{[\mathrm{cm}]}\end{array}$} \\
\hline & & $\begin{array}{l}\text { callus response } \\
{[\%]}\end{array}$ & $\begin{array}{l}\text { SE number } \\
\left.\text { [explant }^{-1}\right]\end{array}$ & $\begin{array}{l}\text { response } \\
{[\%]}\end{array}$ & $\begin{array}{l}\text { SE number } \\
\left.\text { [explant }^{-1}\right]\end{array}$ & \\
\hline $\mathrm{BA}+2 \mathrm{iP}$ & $0.5+1.5$ & $14.67^{\mathrm{i}}$ & $33.67 \pm 1.53^{\mathrm{a}}$ & $25.00^{\mathrm{a}}$ & 1.00 & 0.35 \\
\hline $\mathrm{BA}+\mathrm{KN}$ & $0.5+1.5$ & $20.00^{\mathrm{hi}}$ & $1.67 \pm 0.58^{1}$ & $0.00^{\mathrm{e}}$ & - & - \\
\hline $\mathrm{BA}+\mathrm{IAA}$ & $0.5+0.01$ & $21.67^{\mathrm{ghi}}$ & $4.67 \pm 0.58^{\mathrm{hij}}$ & $11.67^{\mathrm{ab}}$ & 1.00 & 0.30 \\
\hline $\mathrm{BA}+\mathrm{IAA}$ & $0.5+0.1$ & $26.66^{\text {detg }}$ & $5.00 \pm 0.00^{\text {ghi }}$ & $6.67^{b c}$ & - & - \\
\hline $\mathrm{BA}+\mathrm{IAA}$ & $0.5+1.0$ & $33.30^{\mathrm{c}}$ & $6.33 \pm 0.58^{\mathrm{def}}$ & $3.33^{\mathrm{cd}}$ & - & - \\
\hline $\mathrm{BA}+\mathrm{IAA}$ & $0.5+2.0$ & $16.00^{\mathrm{ij}}$ & $5.33 \pm 0.58^{\text {ghij }}$ & $0.00^{\mathrm{d}}$ & - & \\
\hline $\mathrm{BA}+\mathrm{IBA}$ & $0.5+0.01$ & $11.00^{\mathrm{jk}}$ & $5.33 \pm 0.58^{\text {ghij }}$ & $3.30^{\mathrm{cd}}$ & - & - \\
\hline $\mathrm{BA}+\mathrm{IBA}$ & $0.5+0.1$ & $30.00^{\text {cde }}$ & $5.67 \pm 0.58^{\text {fghi }}$ & $0.00^{d}$ & - & - \\
\hline $\mathrm{BA}+\mathrm{IBA}$ & $0.5+1.0$ & $20.00^{\mathrm{hi}}$ & $5.00 \pm 0.00^{\mathrm{ghi}}$ & $0.00^{\mathrm{d}}$ & - & - \\
\hline $\mathrm{BA}+\mathrm{IBA}$ & $0.5+2.0$ & $8.33^{\mathrm{k}}$ & $4.33 \pm 0.58^{\mathrm{ijk}}$ & $0.00^{\mathrm{d}}$ & - & - \\
\hline $\mathrm{BA}+\mathrm{NAA}$ & $0.5+0.01$ & $11.67^{\mathrm{jk}}$ & $5.67 \pm 0.58^{\text {fghi }}$ & $10.00^{\mathrm{ab}}$ & 1.00 & 0.35 \\
\hline $\mathrm{BA}+\mathrm{NAA}$ & $0.5+0.1$ & $33.33^{c}$ & $6.33 \pm 0.58^{\mathrm{def}}$ & $3.35^{\mathrm{cd}}$ & - & - \\
\hline $\mathrm{BA}+\mathrm{NAA}$ & $0.5+1.0$ & $25.00^{\text {efgh }}$ & $6.67 \pm 0.58^{\mathrm{de}}$ & $0.00^{\mathrm{d}}$ & - & - \\
\hline $\mathrm{BA}+\mathrm{NAA}$ & $0.5+2.0$ & $8.33^{\mathrm{k}}$ & $3.67 \pm 0.58^{\mathrm{k}}$ & $0.00^{d}$ & 1.00 & 0.30 \\
\hline $2 \mathrm{iP}+\mathrm{IAA}$ & $1.5+0.01$ & $11.67^{\mathrm{jk}}$ & $5.25 \pm 0.25^{\text {ghij }}$ & $3.30^{\mathrm{cd}}$ & - & - \\
\hline $2 \mathrm{iP}+\mathrm{IAA}$ & $1.5+0.1$ & $28.33^{\text {cdef }}$ & $5.83 \pm 0.29^{\mathrm{fgh}}$ & $10.00^{\mathrm{ab}}$ & 1.00 & 0.40 \\
\hline $2 \mathrm{iP}+\mathrm{IAA}$ & $1.5+1.0$ & $41.67^{\mathrm{b}}$ & $11.33 \pm 0.58^{\mathrm{b}}$ & $0.00^{d}$ & - & - \\
\hline $2 \mathrm{iP}+\mathrm{IAA}$ & $1.5+2.0$ & $8.33^{\mathrm{k}}$ & $6.67 \pm 1.04^{\mathrm{de}}$ & $0.00^{d}$ & - & - \\
\hline $2 \mathrm{iP}+\mathrm{IBA}$ & $1.5+0.01$ & $21.67^{\text {ghi }}$ & $5.92 \pm 0.14^{\mathrm{fgh}}$ & $0.00^{\mathrm{d}}$ & - & - \\
\hline $2 \mathrm{iP}+\mathrm{IBA}$ & $1.5+0.1$ & $23.33^{\text {tgh }}$ & $5.96 \pm 0.14^{\mathrm{fgh}}$ & $0.00^{\mathrm{d}}$ & - & - \\
\hline $2 \mathrm{iP}+\mathrm{IBA}$ & $1.5+1.0$ & $53.33^{\mathrm{a}}$ & $7.25 \pm 0.25^{\mathrm{d}}$ & $3.35^{\mathrm{cd}}$ & - & - \\
\hline $2 \mathrm{iP}+\mathrm{IBA}$ & $1.5+2.0$ & $11.67^{\mathrm{jk}}$ & $5.58 \pm 0.14^{\text {fghi }}$ & $11.67^{\mathrm{ab}}$ & 1.00 & 0.45 \\
\hline $2 \mathrm{iP}+\mathrm{NAA}$ & $1.5+0.01$ & $31.66^{\mathrm{cd}}$ & $9.00 \pm 0.50^{\mathrm{c}}$ & $16.67^{\mathrm{a}}$ & 1.00 & 0.75 \\
\hline $2 \mathrm{iP}+\mathrm{NAA}$ & $1.5+0.1$ & $21.67^{\text {ghi }}$ & $6.33 \pm 0.29^{\mathrm{def}}$ & $11.60^{\mathrm{ab}}$ & - & - \\
\hline $2 \mathrm{iP}+\mathrm{NAA}$ & $1.5+1.0$ & $11.60^{\mathrm{jk}}$ & $5.75 \pm 0.25^{\mathrm{fgh}}$ & $3.30^{\mathrm{cd}}$ & - & - \\
\hline $2 \mathrm{iP}+\mathrm{NAA}$ & $1.5+2.0$ & $8.66^{\mathrm{k}}$ & $3.75 \pm 0.25^{\mathrm{jk}}$ & $0.00^{\mathrm{d}}$ & - & - \\
\hline
\end{tabular}

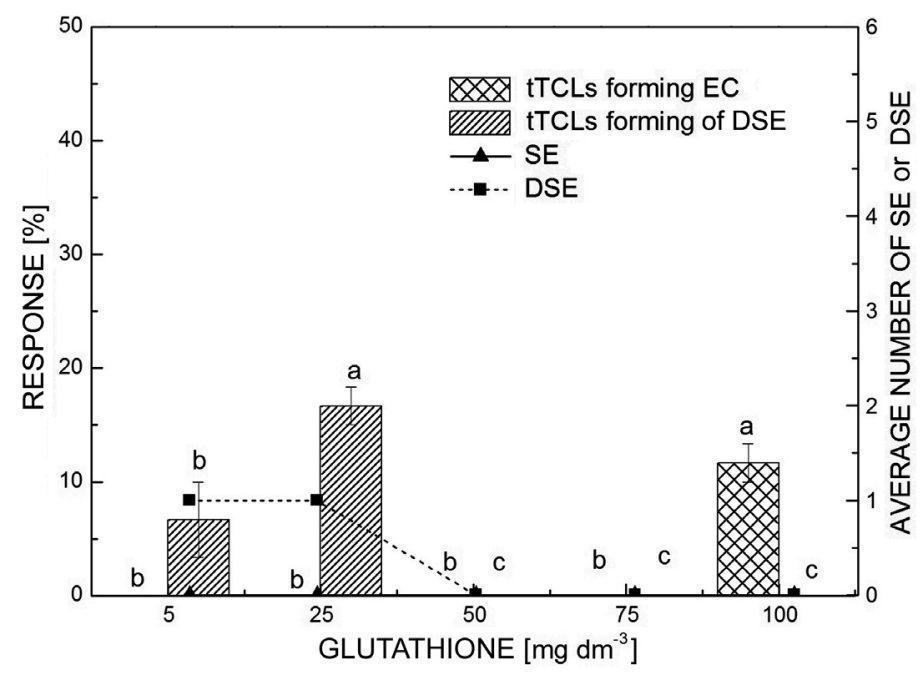

Fig. 4. Embryogenic callus (EC) induction response and somatic embryo (SE) development from stem transverse thin cell layers (tTCLs) of Dendrobium aqueum in response to glutathione. Means \pm SDs, $n=12$, different letters indicate significantly different means $(P \leq 0.05$; DMRT). DSE - direct somatic embryogenesis. 
11 and 7.2 globular SEs per tTCL were recorded when 2iP was combined with $1.0 \mathrm{mg} \mathrm{dm}^{-3} \mathrm{IAA}$ and $1.0 \mathrm{mg} \mathrm{dm}^{-3} \mathrm{IBA}$, respectively (Fig. $1 B$ ). Unlike its combination with $\mathrm{BA}$, NAA at $0.01 \mathrm{mg} \mathrm{dm}^{-3}$ induced 9.0 SEs per tTCL when combined with $1.5 \mathrm{mg} \mathrm{dm}^{-3} 2 \mathrm{iP}$ (Table 2).

When arginine was supplemented at $5-50 \mathrm{mg} \mathrm{dm}^{-3}$, it effectively prevented explant browning and supported both green EC induction and globular SE formation (Fig. 2). However, subsequent somatic embryogenesis was poor, forming only 1.00 PLBs per tTCL at $50 \mathrm{mg} \mathrm{dm}^{-3}$. Antioxidants glutathione and PVP equally inhibited explant browning more than arginine, but glutathione did not induce EC while $0.5 \mathrm{mg} \mathrm{dm}^{-3}$ PVP induced 24.33 SEs per tTCL.

In addition to EC induction, some of the tTCLs with an initial green protuberance induced globular SEs directly on the medium with selected PGRs and additives. The SEs formed either by direct conversion or by emergence from the initial green protuberance of tTCLs. These globular SEs developed PLBs with rhizoids at the basal end and a shoot tip at the opposite pole and did not develop an intermediate callus. All the cytokinins, except only TDZ at $0.1 \mathrm{mg} \mathrm{dm}^{-3}$, induced a single SE in $8.33 \%$ of explants (Table 1, Fig. $1 H-J$ ) whereas the $\mathrm{BA}+2 \mathrm{iP}$ combination yielded a higher frequency $(25.00 \%)$ of embryo induction with no increment in the number of SEs (Table 2). Synergistic treatments, BA and 2iP with different auxins, showed only a slight improvement on direct SE induction than the individual treatments, but not higher than $\mathrm{BA}+2 \mathrm{iP}$. In terms of cytokinin +auxin combinations, a maximum response of $16.67 \%$ of explants induced direct SEs on the medium with $1.5 \mathrm{mg} \mathrm{dm}^{-3} 2 \mathrm{iP}$ and $0.01 \mathrm{mg} \mathrm{dm}^{-3}$ NAA (Table 2). All auxins at a high concentration of $2.0 \mathrm{mg} \mathrm{dm}^{-3}$ (except for IBA) when combined with $2 \mathrm{iP}$ or BA failed to form SEs directly. The use of additives at low concentrations increased direct SE formation in 2iP+IBA combination. Most tTCLs (50\%) formed one SE directly in response to $25 \mathrm{mg} \mathrm{dm}^{-3}$ arginine (Fig. 2) whereas on the medium with $0.3 \mathrm{mg} \mathrm{dm}^{-3}$ PVP, 1.5 SEs per TCL was formed on a maximum of $33.33 \%$ explants (Figs. $1 K$ and 3 ). Glutathionesupplemented medium resulted in a stunted shoot growth.

Finally, more than $90 \%$ of the hardened plantlets survived after three to four weeks in the greenhouse. No variations was observed in morphology and growth characteristics among the potted plantlets. Genetic fidelity analysis attempted with 5 ISSR primers produced scorable bands from 325 to 1900 bp (Table 2 Suppl., Fig. 2 Suppl.). All the five primers, collectively produced 45 scorable bands, of which $44(97.78 \%)$ bands were monomorphic. This revealed the genetic fidelity of the plants raised through somatic embryos. Primer I2 produced only 1 polymorphic band $(2.22 \%)$ out of 11 bands.

\section{Discussion}

In orchids, TCLs have been prepared from shoots, stem nodes, or PLBs (Table 1 Suppl.). TCLs have been widely

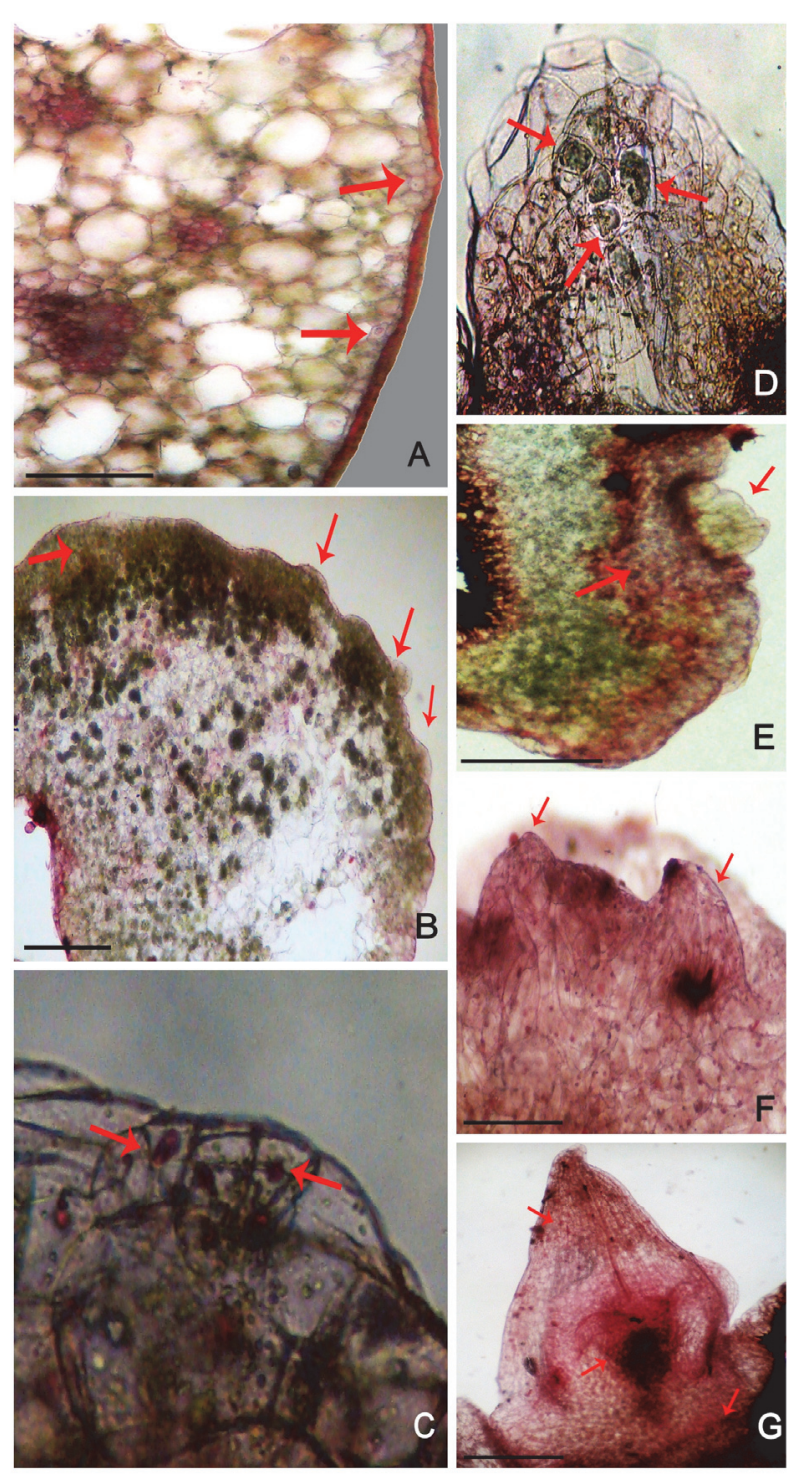

Fig. 5. Histology of stem transverse thin cell layers (tTCLs), callus and protocorm-like bodies (PLBs) of Dendrobium aqueum. $A$ - Hand-made section of a stem tTCL showing small polyhedral cells (SPC) in sub-epidermal regions (the arrows); $B$ - a green compact embryogenic callus (EC) showing dense meristematic regions, with multiple protuberances of somatic embryo (SE) initials (the arrows); $C$ and $D$ - embryogenic cells with dense cytoplasm, a prominent nucleus, and vacuoles showing both anticlinal (AC) and periclinal (PC) divisions on $\mathrm{EC}$ (the arrows); $E$ and $F$ - formation of globular SE on EC surface and protuberance from the meristematic regions of ECs; $G$ - an SE derived protocorm-like body (PLB) with a leafy shoot initial (the upper arrow) and a dense meristematic protocorm (the middle arrow), not connected with the EC (the lower arrow). Scale bars: $100 \mu \mathrm{m}(A$ and $B), 200 \mu \mathrm{m}(E$ and $F)$, and $650 \mu \mathrm{m}(G)$.

applied in tissue culture, somatic embryogenesis, and genetic transformation of many higher plants including 
orchids (Teixeira da Silva 2003, 2013). A previous study on the in vitro propagation of $D$. aqueum induces multiple shoots from protocorms on a half-strength MS medium supplemented with cytokinins, auxins, and additives (Parthibhan et al. 2015a). Unlike that study, where the regeneration of shoots was completely organogenic showing clear vascular traces connecting the shoot to the explant, in the present study, regeneration from stem tTCLs occurred mostly through the formation of EC leading to SE development, without any vascular traces (Fig. 1A,D, 5C). Previous studies on Dendrobium TCLs produced either direct PLBs or shoot buds, and the outcome and frequency were related to the species and the type of explant used (Table 1 Suppl.). The SE development started with the formation and appearance of globular or slightly elliptic structures from a compact or friable EC. These structures were very similar to the swollen embryos of germinating seeds (i.e., protocorms) in D. aqueum (Parthibhan et al. 2012). On development, these globular SEs formed PLBs; additionally, there were successive stages of somatic embryogenesis where heartand torpedo-shaped structures formed. It is common for monocotyledonous species to have no general stages of embryogenesis, unlike dicotyledonous species. There are different developmental patterns in monocotyledonous somatic embryogenesis that make it difficult to generalize different stages (Hirimburegama 1995). Nevertheless, somatic embryogenesis in monocots may be specific to a particular species, genus, or family (Poddudanya-Arnoldi 1967, Natesh and Rao 1984). Developing globular SEs in monocots comprises an incipient shoot meristem and a single cotyledonary primordium side by side, which makes them appear asymmetric, unlike in dicots (Jürgens et al. 1994). Similar asymmetric shapes have been reported in several monocotyledonous species, equivalent to heart (Halophila), torpedo, and cotyledonary stages (Phoenix dactylifera), torpedo, heart, and globular embryos (Triticum aestivum), and torpedo shape (Agave tequilana) have been reported in several monocotyledonous species (Jürgens et al. 1994, GutiérrezMora et al. 2004, Eshraghi et al. 2005, Portillo et al. 2007, Shahinul Islam 2010, Gutiérrez-Mora et al. 2012).

Explant browning followed by necrosis on a PGR-free basal medium, in our case on a half-strength MS, occurs mainly due to lack of plant growth-promoting substances as was reported in $D$. nobile, D. candidum, and D. draconis (Malabadi et al. 2005, Zhao et al. 2007, Rangsayatorn 2009). In contrast, around 2 - $3 \%$ of TCLs of Cymbidium aloifolium and D. nobile TCLs cultured on a MS basal medium containing full-strength macronutrients induced 1 - 2 PLBs per TCL (Nayak et al. 2002).

The addition of individual cytokinins to TCL culture has been reported to encourage the frequency of EC and multiple SE formation in many orchids (Hossain et al. 2013). Of the five cytokinins tested in this study, EC induction was more efficient on ZEA than BA and 2iP, although SE formation was significantly lower on ZEA than on 2iP and BA. Similarly, TCLs obtained from
D. nobile PLBs also fail to induce and multiply PLBs on a medium with ZEA (Nayak et al. 2002). In contrast, ZEA and ZEA riboside formed many SEs or PLBs from different explants (a root-derived callus and leaf), including TCLs of PLBs in other orchids, namely Cymbidium aloifolium and Oncidium spp. (Chen and Chang 2001, Nayak et al. 2002, Wu et al. 2004). These studies indicate that ZEA can efficiently induce EC, but the frequency of response and embryogenic outcome may depend on the explant type and species. Moreover, TCLs from PLBs and callus used in these studies, often comprising an undifferentiated mass of meristematic cells, resulted in a higher frequency of embryogenic response than the TCLs derived from leaf explants. Similarly, in our study, tTCLs obtained from the stems of D. aqueum, composed of highly differentiated cells with few meristematic cells, displayed a lower frequency of EC. The presence of other tissues or even other nutrients and PGRs present at the site of regeneration may be responsible for a lower frequency of EC induction from tTCLs (Lakshmanan et al. 1995).

The outcome of SE formation was highly contingent on the cytokinin used. Previous reports that employed TCLs for D. gratiosissimum, D. draconis, and D. nobile showed the highest PLB production only with individual cytokinins, e.g., $2.0 \mathrm{mg} \mathrm{dm}^{-3} \mathrm{KN}$ or 2.5 and $5.0 \mathrm{mg} \mathrm{dm}^{-3}$ BA (Nayak et al. 2002, Rangsayatorn 2009, Jaiphet and Rangsayatorn 2010). Individual cytokinins (2iP, BA, KN, ZEA, and TDZ) have also been reported to induce direct SEs from leaf explants of Dendrobium cv. Chiengmai Pink (Chung et al. 2005) whereas tTCLs obtained from the nodes of $D$. candidum produced direct shoot buds on a BA-containing medium more than on $\mathrm{KN}$ or NAA (Zhao et al. 2007). Similar responses of PLB or SE induction by individual cytokinins were recorded in other orchid species, such as Phalaenopsis cornucervi and Oncidium spp,. using different explants (Chen and Chang 2001, Wu et al. 2004, Rittirat 2012). In this study, SEs that formed in response to $0.5 \mathrm{mg} \mathrm{dm}^{-3} \mathrm{ZEA}$ turned necrotic whereas the EC induced on $1.5 \mathrm{mg} \mathrm{dm}^{-3} 2 \mathrm{PP}$ or $0.5 \mathrm{mg} \mathrm{dm}^{-3} \mathrm{BA}$ produced a high number of SEs (42.67 and 16.00 SEs per tTCL, respectively), which then developed to successive stages of SEs (Table 1). When these optimal levels were exceeded, intense yellow callus was formed with a reduced number or no PLBs, similar to a report on Aranda nodal TCLs (Lakshmanan et al. 1995). These results indicate that the outcome of EC proliferation and SE production in Dendrobium are dependent on the PGRs used as well as on the explant type. This is further evidenced by an experiment from PLB-derived TCLs, in which zeatin riboside induces more PLBs in $C$. aloifolium whereas BA forms more PLBs in D. nobile (Nayak et al. 2002).

Of all the combined treatments tested, BA with $2 \mathrm{iP}$ increased SE formation considerably (33.67 SEs per tTCL) rather than inducing a callus. Likewise, $2 \mathrm{iP}$ in combination with auxins also formed slightly more SEs and a higher EC frequency than any BA+auxin combination (Table 2). To date, the synergistic ability of 
2iP on somatic embryogenesis has not yet been reported for any Dendrobium genotype. On the other hand, BA $\left(0.5 \mathrm{mg} \mathrm{dm}^{-3}\right)$ combined with $\mathrm{KN}\left(1.5 \mathrm{mg} \mathrm{dm}^{-3}\right)$ or with auxins improved the EC response more than individual treatments, but SE formation was highly reduced (Table 2). The BA+NAA combination has constantly been reported to improve EC induction or PLB production in Dendrobium including when TCLs have been used (Kanjilal et al. 1999, Nhat and Dung 2006, Rangsayatorn 2009, Teixeira da Silva et al. 2015a, Table 1 Suppl.). However, the combinations $\mathrm{BA}+\mathrm{KN}$ and BA+IAA used in this study were less effective than the 2iP+IAA combination. KN, when used alone, appeared to inhibit the activity of BA during both callus induction and SE formation. Unlike $\mathrm{KN}$, all other auxins used with BA enhanced the frequency of EC but inhibited SE development due to necrosis (Table 2). A similar negative influence of $\mathrm{KN}$ on PLB production has already been reported in Oncidium cv. Gower Ramsey, D. nobile, and D. draconis (Chen and Chang 2001, Nayak et al. 2002, Rangsayatorn 2009).

Amino acids are infrequently used in orchid tissue culture except for some seed germination studies (Hossain et al. 2013). Somatic embryogenesis using amino acids has been reported in other plants, including Phoenix dactylifera (Sghaier et al. 2009) and Saccharum spontaneum (Nieves et al. 2008). Amino acids, especially arginine, promote accumulation of soluble protein in embryogenic calluses during SE differentiation and maturation (Lee et al. 2007, Nieves et al. 2008, Sghaier et al. 2009). Moreover, amino acids are the constituents of seed storage proteins and play an important role in germination and seedling development (Muntz 1998). For these reasons, it is likely that the early green protuberances and EC initials subsequently developed into plantlets after PLBs formed in D. aqueum in response to arginine. The rapid shoot bud development from PLBs and EC achieved in this study in response to 25 to $50 \mathrm{mg} \mathrm{dm}^{-3}$ arginine was also observed in Cymbidium pumilum and C. goeringii (Ueda and Torikata 1968, 1972, Nieves et al. 2008).

Browning explant tissues and a regenerative callus ultimately leading to necrosis are major problems in orchid somatic embryogenesis (Wu et al. 2004, Roy et al. 2007, Majumder et al. 2010). In orchids, when explants are obtained from mature plants, they either release exudates into the medium or accumulate phenolic substances within their tissues during culture, and these become toxic to cells when oxidized (Chugh et al. 2009, Kaewubon et al. 2015). In the present study, the stems used to obtain tTCLs were about $5 \mathrm{~cm}$ in height and $2-3$ $\mathrm{mm}$ in diameter, green and hard. There was no exudation during the preparation of tTCLs whereas after 3 - 4 weeks in culture, the edges of some of the explants turned brown and explants became necrotic. Apart from the negative impact on explants, callus browning affected callus proliferation and SE formation. The PGR concentrations and combinations used induced explant browning at various levels, $0-100 \%, 9-66 \%$, and $0-86 \%$ in
D. fimbriatum, D. farmeri, and Dendrobium cv. Indonesia Raya, respectively (Roy and Banerjee 2003, Majumder et al. 2010, Rachmawati et al. 2015). In our study, some of the callus that turned completely brown, as well as the explant from which it formed, initiated green EC and continued to proliferate, and could be subcultured to form shoots. This might be due to the regenerative competence of PGRs on stem TCLs of D. aqueum similarly as reported earlier in D. crepidatum and D. pierardianum (Vij et al. 1991), and Coelogyne stricta (Basker and Narmatha Bai 2006), where regenerated shoot buds grow normally with the help of PGRs even after the explants become brown.

Active charcoal is frequently employed to control explant browning (tissue oxidation) and to promote in vitro micropropagation, somatic embryogenesis, synthetic seed production, protoplast culture, anther and microspore culture, and rooting in plants, including orchids (Sharma et al. 2007, Thomas 2008, Rittirat et al. 2012, Teixeira da Silva et al. 2015a). In this study, AC controlled browning effectively, but completely failed to support callus induction. Similarly, glutathione did not support EC induction. In general, when glutathione is supplemented to culture medium, rooting is favoured, EC fresh mass and SE yield increase, and it can effectively protect in vitro cultured tissues against oxidative stress (Tyburski and Tretyn 2010). In the present study, 5 to $75 \mathrm{mg} \mathrm{dm}^{-3}$ arginine did not induce callus, and callus that formed at a higher concentration $\left(100 \mathrm{mg} \mathrm{dm}^{-3}\right)$ became necrotic (Fig. 4). On the other hand, lower concentrations of glutathione $\left(5-25 \mathrm{mg} \mathrm{dm}{ }^{-3}\right)$ directly induced SEs, which turned immediately into shoots via PLBs (Fig. 4). The ratio of reduced to oxidized glutathione can influence cell extension, growth, and division (Standardi and Micheli 1988). This might explain the direct formation of SEs rather than via callus in D. aqueum. Unlike AC and glutathione, PVP significantly inhibited explant browning and supported EC induction following SE formation as well as direct SE formation (Fig. 3). The addition of PVP to the culture medium helps to oxidize polyphenols, which are released by explants into the medium and promotes organogenesis (Rout et al. 2006). However, in this study, the rate of conversion of initial green protuberances into direct SEs was observed at low concentrations of PVP $\left(0.1-0.3 \mathrm{mg} \mathrm{dm}^{-3}\right)$, proliferation of EC at $0.3-0.5 \mathrm{mg} \mathrm{dm}^{-3} \mathrm{PVP}$, and effective formation of SEs at $0.5 \mathrm{mg} \mathrm{dm}^{-3}$ PVP (Fig. 3).

Overall, the plantlets obtained from SEs showed no morphological variation among the treatments (Fig. $1 G$ ). Generally, the use of synthetic PGRs at sub- and supraoptimal levels supposedly induce somaclonal variation in orchids (Arditti and Ernst 1993). However, the ISSR marker profiles of the SE-derived D. aqueum plants showed a high rate of monomorphism (97.78\%) and confirmed the genetic fidelity of plantlets derived from various PGR treatments.

In conclusion, this is the first report on somatic embryogenesis of $D$. aqueum from stem tTCLs. We also report the successive maturation stages of $D$. aqueum 
SEs. The individual and combined effects of cytokinins, auxins, arginine, glutathione, and/or PVP on somatic embryogenesis until the shoot development in D. aqueum

\section{References}

Arditti, J., Ernst, R.: Micropropagation of Orchids. - John Wiley and Sons, New York 1993.

Basker, S., Narmathabai, V.: Micropropagation of Coelogyne stricta (D. Don) Schltr via pseudobulb segment culture. Trop. Subtrop. Agroecosys. 6: 31-35, 2006.

Chen, J.T., Chang, W.C.: Effects of auxins and cytokinins on direct somatic embryogenesis on leaf explants of Oncidium 'Gower Ramsey'. - Plant Growth Regul. 34: 229-232, 2001.

Chugh, S., Guha, S., Rao, U.: Micropropagation of orchids: a review on the potential of different explants. - Sci. Hort. 122: 507-520, 2009.

Chung, H.H., Chen, J.T., Chang, W.C.: Cytokinins induce direct somatic embryogenesis of Dendrobium Chiengmai Pink and subsequent plant regeneration. - In Vitro cell. dev. Biol. Plants 41: 765-769, 2005.

Duncan, D.B.: Multiple range and multiple F tests. - Biometrics 11: $1-42,1955$.

Eshraghi, P., Zarghami, R., Mirabdulbaghi, M.: Somatic embryogenesis in two Iranian date palm cultivars. - Afr. J. Biotechnol. 4: 1309-1312, 2005.

Gutierrez, R.M.P.: Orchids: a review of uses in traditional medicine, its phytochemistry and pharmacology. - J. med. Plants Res. 4: 592-638, 2010.

Gutiérrez-Mora, A., González-Gutiérrez, A.G., Rodríguez-Garay, B., Ascencio-Cabral, S., Li, W.-L.: Plant somatic embryogenesis: some useful considerations. - In: Sato, K.-I. (ed.): Embryogenesis. Pp. 229-248. InTech. (http:// cdn.intechopen.com/pdfs-wm/35568) 2012.

Gutiérrez-Mora, A., Ruvalcaba-Ruíz, D., Rodríguez-Domínguez, J.M., Loera-Quezada, M.M., Rodríguez-Garay, B.: Recent advances in the biotechnology of Agave: a cell approach. - In Pandalai, S.G. (ed.): Recent Research Developments in Cell Biology. Vol. 2. Pp. 12-26. Transworld Research Network, Kerala 2004.

Hirimburegama, K.: In vitro somatic embryogenesis in angiosperms with special reference to monocotyledons. Vidyodaya J. Sci. 1: 1-19, 1995.

Hossain, M.M., Kant, R., Van, P.T., Winarto, B., Zeng, S.J., Teixeira da Silva, J.A.: The application of biotechnology to orchids. - Crit. Rev. Plant Sci. 32: 69-139, 2013.

Jaiphet, C., Rangsayatorn, N.: Micropropagation of a rare orchid Dendrobium gratiosissimum Rchb.f., using thin cell layers. Acta hort. 878: 185-189, 2010.

Jürgens, G., Torres Ruiz, R.A., Berleth, T.: Embryonic pattern formation in flowering plants. - Annu. Rev. Genet. 28: 351371, 1994.

Kaewubon, P., Hutadilok-Towatana, N., Teixeira da Silva, J.A., Meesawat, U.: Ultrastructural and biochemical alterations during browning of pigeon orchid (Dendrobium crumenatum Swartz) callus. - Plant Cell Tissue Organ Cult. 121: 53-69, 2015.

Kanjilal, B., De Sarkar, D., Mitra, J., Datta, K.B.: Stem disc culture: development of a rapid mass propagation method for Dendrobium moschatum (Buch. - Ham.) Swartz - an endangered orchid. - Curr. Sci. 77: 497-300, 1999.

Knudson, L.: A new nutrient solution for the germination of orchid seeds. - Amer. Orchid. Soc. Bull. 15: 214-217, 1946.

Kumar, C.S., Shetty, B.V., Bennet, S.S.R., Rao, T.A., Molur, S., could be applied to the regeneration of other important orchids.

Walker, S. (ed.): Endemic Orchids of the Western Ghats. Conservation Assessment and Management Plan (C.A.M.P.) Workshop. - Wildlife Information Liaison Development Society and Zoo Outreach Organisation, Coimbatore 2001.

Lakshmanan, P., Loh, C.S., Goh, C.J.: An in vitro method for rapid regeneration of a monopodial orchid hybrid Aranda Deborah using thin section culture. - Plant Cell Rep. 14: 510514, 1995.

Lee, Y.I., Hsu, S.H., Yeung, E.: Orchid protocorm-like bodies are somatic embryos. - Amer. J. Bot. 100: 2121-2131, 2013.

Lee, Y.I., Yeung, E.C., Chung, M.C.: Embryo development in orchids. - In: Chen, W.H., Chen, H.H. (ed.): Orchid Biotechnology. Pp. 23-44. World Scientific, Singapore 2007.

Majumder, M., Maiti, S.S., Banerjee, N.: Direct and callus mediated protocorm like body induction and high frequency adventitious shoot regeneration in an endangered orchid Dendrobium farmeri Paxt. (Orchidaceae). - Floricult. Ornamen. Biotechnol. 4: 22-28, 2010.

Malabadi, R.B., Mulgund, G.S., Kallappa, N.: Micro-propagation of Dendrobium nobile from shoot tip sections. - J. Plant. Physiol. 162: 473-478, 2005.

Maridass, M., Zahir Hussain, M.I., Raju, G.: Phytochemical survey of orchids in Tirunelveli hills of South India. Ethnobot. Leaflets 12: 705-712, 2008.

Matthew, K.M.: The Flora of the Tamil Nadu Carnatic. Vol. I-III. The Rapinat Herbarium - St. Josephs College, Tiruchirappalli 1983.

Misra, S.: Orchids of India - A glimpse. - Bishen Singh Mahendra Pal Singh, Dehradun 2007.

Mukherjee, S., Phatak, D., Parikh, J., Jagtap, S., Shaikh, S., Tupe, R.: Antiglycation and antioxidant activity of a rare medicinal orchid Dendrobium aqueum Lindl. - Med. Chem. Drug Discovery 2: 46-54, 2012.

Muntz, K.: Deposition of storage proteins. - Plant mol. Biol. 38: 77-99, 1998.

Murashige, T., Skoog, F.: A revised medium for rapid growth and bioassays with tobacco cultures. - Physiol. Plant 15: 473-497, 1962.

Natesh, S., Rao, M.A.: The embryo. - In: Johri, B.M. (ed.): Embryology of Angiosperms. Pp. 377-443. Springer-Verlag, Berlin 1984.

Nayak, N., Sahoo, S., Patnaik, S., Rath, S.: Establishment of thin cross section (TCS) culture method for rapid micropropagation of Cymbidium aloifolium (L) Sw. and Dendrobium nobile Lindl. (Orchidaceae). - Sci. Hort. 94: 107-116, 2002.

Nhat, N.T.H., Dung, T.T.: In vitro propagation of Dendrobium orchid through thin stem section culture. - In: Proceedings of International Workshop on Biotechnology in Agriculture. Pp. 154-155. Nong Lam University, Ho Chi Minh City 2006.

Nieves, N., Sagarra, F., Gonzalez, R., Lezcano, Y., Cid, M., Blanco, M.A., Castillo, R.: Effect of exogenous arginine on sugarcane (Saccharum sp.) somatic embryogenesis, free polyamines and the contents of the soluble proteins and proline. - Plant Cell Tissue Organ Cult. 95: 313-320, 2008.

Parthibhan, S., Benjamin, J.H.F., Muthukumar, M., Ahamed Sherif, N., Senthil Kumar, T., Rao, M.V.: Influence of nutritional media and photoperiods on in vitro asymbiotic 
seed germination and seedling development of Dendrobium aqueum Lindley. - Afr. J. Plant Sci. 6: 383-393, 2012.

Parthibhan, S., Senthil Kumar, T., Rao, M.V.: In vitro regeneration from protocorms in Dendrobium aqueum Lindley - an imperilled orchid. - J. Genet. Eng. Biotechnol. 13; 227-233, 2015a.

Parthibhan, S., Senthil Kumar, T., Rao, M.V.: Phenology and reintroduction strategies for Dendrobium aqueum Lindley an endemic, near threatened orchid. - J. Natur. Conserv. 24: $68-71,2015 b$

Poddudanya-Arnoldi, V.A.: Comparative embryology of the Orchidaceae. - Phytomorphology 17: 312-320, 1967.

Portillo, L., Santacruz-Ruvalcaba, F., Gutiérrez-Mora, A., Rodríguez-Garay, B.: Somatic embryogenesis in Agave tequilana Weber cultivar Azul. - In Vitro cell. dev. Biol. Plant 43: 569-575, 2007.

Rachmawati, F., Winarto, B., Mattjik, N.A., Wiendi, N.M.A., Purwito, A.: Shoot tips derived-somatic embryogenesis in mass propagation of Dendrobium Indonesia Raya 'Ina'. Emirates J. Food Agr. 27: 1-10, 2015.

Rangsayatorn, N.: Micropropagation of Dendrobium draconis Rchb.f. from thin cross-section culture. - Sci. Hort. 122: 662$665,2009$.

Rittirat, S., Kongruk, S., Te-Chato, S.: Induction of protocormlike bodies (PLBs) and plantlet regeneration from wounded protocorms of Phalaenopsis cornucervi (Breda) Blume \& Rchb. f. - J. Agr. Technol. 8: 2397-2407, 2012.

Rout, G.R., Mohapatra, A., Jain, S.M.: Tissue culture of ornamental pot plant: a critical review on present scenario and future prospects. - Biotechnol. Adv. 24: 531-560, 2006.

Roy, J., Banerjee, N.: Induction of callus and plant regeneration from shoot tip explants of Dendrobium fimbriatum Lindl. var. oculatum Hk.f. - Sci. Hort.. 97: 333-340, 2003.

Roy, J., Naha, S., Majumdar, M., Banerjee, N.: Direct and callusmediated protocorm-like body induction from shoot-tips of Dendrobium chrysotoxum Lindl. (Orchidaceae). - Plant Cell Tissue Organ Cult. 90: 31-39, 2007.

Sghaier, B., Kriaa, W., Bahloul, M., Novo, J.V.J., Drira, N.: Effect of ABA, arginine and sucrose on protein content of date palm somatic embryos. - Sci. Hort. 120: 379-385, 2009.

Shahinul Islam, S.M.: Effect of embryoids age, size and shape for improvement of regeneration efficiency from microsporederived embryos in wheat (Triticum aestivum L.). - Plant Omics 3: 149-153, 2010.

Sharma, U., Rao, V.R., Mohan, J.S.S., Reddy, A.S.: In vitro propagation of Dendrobium microbulbon A. Rich - a rare ethno medicinal herb. - Indian J. Biotechnol. 6: 381-384, 2007.

Standardi, A., Micheli, M.: Control of vitrification in proliferating shoots of M-26. - Acta hort. 227: 425-427, 1988.

Sudhakar Reddy, C., Pattanaik, C., Murthy, M., Reddy, K.: Orchid's flora of Eastern Ghats, India. - Environmental Information System Programme (ENVIS) Newslett. 11 (4): 6$12,2005$.

Teixeira da Silva, J.A.: Thin cell layer technology in ornamental plant micropropagation and biotechnology. - Afr. J. Biotechnol. 2: 683-691, 2003.

Teixeira da Silva, J.A.: The role of thin cell layers in regeneration and transformation in orchids. - Plant Cell Tissue Organ Cult. 113: 149-161, 2013.

Teixeira da Silva, J.A.: Should the term protocorm-like body be used exclusively for orchids? - J. Plant Dev. 21: 161-166, 2014.

Teixeira da Silva, J.A., Dobránszki, J.: Plant thin cell layers: a 40- year celebration. - J. Plant Growth Regul. 32: 922-943, 2013.

Teixeira da Silva, J.A., Dobránszki, J., Cardoso, J.C., Zeng, S.J.: Dendrobium micropropagation: a review. - Plant Cell Rep. 34: 671-704, 2015a.

Teixeira da Silva, J.A., Ng, T-B.: The medicinal and pharmaceutical importance of Dendrobium species. - Appl. Microbiol. Biotechnol. 101: 2227-2239, 2017.

Teixeira da Silva, J.A., Singh, N., Tanaka, M.: Priming biotic factors for optimal protocorm-like body and callus induction in hybrid Cymbidium (Orchidaceae), and assessment of cytogenetic stability in regenerated plantlets. - Plant Cell Tissue Organ Cult. 84: 135-144, 2006.

Teixeira da Silva, J.A., Tsavkelova, E., Ng, T.B., Dobránszki, J., Parthibhan, S., Cardoso, J.C., Rao, M.V., Zeng, S.J.: Asymbiotic in vitro seed propagation of Dendrobium. - Plant Cell Rep. 34: 1685-1706, 2015b.

Teixeira da Silva, J.A., Tsavkelova, E., Zeng, S.J., Ng, T.B., Dobránszki, J., Parthibhan, S., Cardoso, J.C., Rao, M.V.: Symbiotic in vitro seed propagation of Dendrobium: fungal and bacterial partners and their influence on plant growth and development. - Planta 242: 1-22, 2015c.

Teixeira da Silva, J.A., Winarto, B.: Somatic embryogenesis in two orchid genera (Cymbidium, Dendrobium). - In: Germanà, M.A., Lambardi, M. (ed.): In vitro Plant Embryogenesis in Higher Plants. Pp. 371-386. Springer, Berlin 2016.

Thomas, T.D.: The role of activated charcoal in plant tissue culture. - Biotechnol. Adv. 26: 618-631, 2008.

Tyburski, J., Tretyn, A.: Ascorbate and glutathione in organogenesis, regeneration and differentiation in plant in vitro cultures. - In: Anjum, N.A., Chan, M., Umar. S. (ed.): Ascorbate - Glutathione Pathway and Stress Tolerance in Plants. Pp. 55-90. Springer, Berlin, 2010.

Ueda, H., Torikata, H.: Organogenesis in meristem culture of Cymbidium. I. Studies on the effects of growth substances added to culture media under continuous illumination. - J. jap. Soc. hort. Sci. 37: 240-248, 1968.

Ueda, H., Torikata, H.: Effects of light and culture medium on adventitious root formation by Cymbidium in aseptic culture. - Amer. Orchid Soc. Bull. 41: 322-327, 1972.

Vij, S.P., Sood, A., Sharma, M.: Morphogenetic response of floral buds of Dendrobium: A study in vitro. - In: Proceedings of National Seminar on Biology, Improvement, Propagation and Commercialization of Indian orchids. Pp. 40-41. Bangalore 1991.

Vyas, S., Guha, S., Kapoor, P., Rao, I.U.: Micropropagation of Cymbidium Sleeping Nymph through protocorm-like bodies production by thin cell layer culture. - Sci. Hort. 123: 551557,2010

Wang, H.Z., Feng, S.G., Lu, J.J., Shi, N.N., Liu, J.J.: Phylogenetic study and molecular identification of 31 Dendrobium species using inter simple sequence repeat (ISSR) markers. - Sci. Hort. 122: 440-447, 2009.

$\mathrm{Wu}$, I.F., Chen, J.T., Chang, W.C.: Effects of auxins and cytokinins on embryo formation from root-derived callus of Oncidium 'Gower Ramsey'. - Plant Cell Tissue Organ Cult. 77: 107-109, 2004.

Yu, H., Goh, C.J.: Differential gene expression during floral transition in an orchid hybrid Dendrobium Madame Thong. Plant Cell Rep. 19: 926-931, 2000.

Zhao, P., Wang, W., Feng, F.S., Wu, F., Yang, Z.Q., Wang, W.J.: High frequency shoot regeneration through transverse thin cell layer culture in Dendrobium candidum Wall ex Lindl. Plant Cell Tissue Organ Cult. 90: 131-139, 2007. 